\title{
FISH SPECIES COMPOSITION, DISTRIBUTION AND CONSERVATION IN THE WUYI MOUNTAINS, CHINA
}

\author{
SHI, Z. M. ${ }^{1}$ - HU, X. M. ${ }^{1}$ - LIN, M. R. ${ }^{1}-$ TANG, X. L. ${ }^{1}-$ YANG, J. H. ${ }^{1}$ - HU, M. L. ${ }^{1,2,3 *}$ \\ ${ }^{I}$ School of Life Sciences, Nanchang University, Nanchang, Jiangxi, P. R. China \\ ${ }^{2}$ Ministry of Education Key Laboratory of Poyang Lake Environment and Resource Utilization, \\ Nanchang University, Nanchang, Jiangxi, P. R. China \\ ${ }^{3}$ Jiangxi Key Laboratory of Aquatic Animal Resource and Utilization, Nanchang University, \\ Nanchang, Jiangxi, P. R. China \\ *Corresponding author \\ e-mail: humaolin@ncu.edu.cn; phone: +86-791-8525-6500
}

(Received $15^{\text {th }}$ Apr 2019; accepted $4^{\text {th }}$ Jul 2019)

\begin{abstract}
According to the fish checklist of 16 nature reserves in the Wuyi Mountains of China, a total of 126 freshwater fish species belonging to 5 orders and 17 families were present. Cypriniformes (consisting of 101 species and accounting for $69.8 \%$ of the total) was the major components of the fish fauna. And species of family Cyprinidae comprised $51.6 \%$ of the total and classified into 10 subfamilies. Overall, 72 species $(57.1 \%$ of the total) were endemic to China. The comparison of species richness, endemic species richness and values of F-index, G-index and G-F index between the west and east slopes of Wuyi Mountains showed that there was a higher fish species diversity in the east slope. And among the three districts (i.e. the north, middle and south sections of Wuyi Mountains), fish species diversity was highest at the north section, good at the middle section and lowest at the south section. We divided 16 nature reserves into two regions according to geographical location and four regions according to river type through cluster analysis. Current threats to conservation of fish species diversity in the Wuyi Mountains were reviewed and management solutions were suggested.
\end{abstract}

Keywords: freshwater fish, species diversity, nature reserve, Jiangxi Province, Fujian Province

\section{Introduction}

The Wuyi Mountains is located in the southeast of China, and on the borderline between Jiangxi and Fujian province (Fig. 1a). It runs from the northeast to southwest with a length of about $540 \mathrm{~km}$, and the highest peak is up to $2158 \mathrm{~m}$. Therefore, the mountain range had been given "roof of the East China" (Guan, 2016). Streams in the mountain range flow into the Yangtze, Oujiang, Minjiang and Hanjiang rivers which drain into the East and South China seas (Fig. 1b). And the mountain range presents a subtropical humid monsoon climate with four distinct seasons. The annual average precipitation of Wuyi mountain is $1600 \mathrm{~mm}$ and $2000 \mathrm{~mm}$, and the mean annual temperature range is from 17 to $20^{\circ} \mathrm{C}$, and annual average relative humidity was up to $78 \%$ (Guan, 2016).

In addition, the mountain range is a key area for the conservation of biodiversity in Chinese ecosystems. And it preserves the most typical, intact and largest zonal evergreen broad-leaved forest and subtropical forest ecosystems at the same latitudinal band of the world, so the mountain range had been called the "natural botanical garden", "insect world", "avian paradise" and so on (Liu et al., 2012). Fujian Wuyishan Nature Reserve (NR), the first national nature reserve, was created in 1979. By 2015, 45 nature reserves of different grades and types were established including 15 national 
NRs, 14 provincial NRs, one city-level NR and 15 county-level NRs. Except for one paleontological relic reserve and seven wildlife reserves, the others are forest ecological reserves (Ministry of Ecology and Environment of the PRC, 2016). Among the 45 NRs, Tongboshan NR, Jiangxi Wuyishan NR, Yangjifeng NR, Matoushan NR, Ganjiangyuan NR, Jinpenshan NR, Lingyunshan NR, Laohunao NR, Fengyangshan NR, Fujian Wuyishan NR, Emeifeng NR, Minjiangyuan NR, Longxishan NR, Junzifeng NR, Tianbaoyan NR, and Guilongshan NR were investigated on fish species diversity. The Wuyi Mountains can be divided into two areas (east slope and west slope), the boundary between east slope and west slope is the ridge of Wuyi Mountains, not only important in physical geography, but also divided Jiangxi Province and Fujian Province. From north to south, the altitude of Wuyi Mountain ranges is getting lower, and can be divided into three regions (north section, middle section and south section) through the geographical division and the description of the location in the investigation report of the nature reserve (Zhong, 2004; Chen et al., 2009).

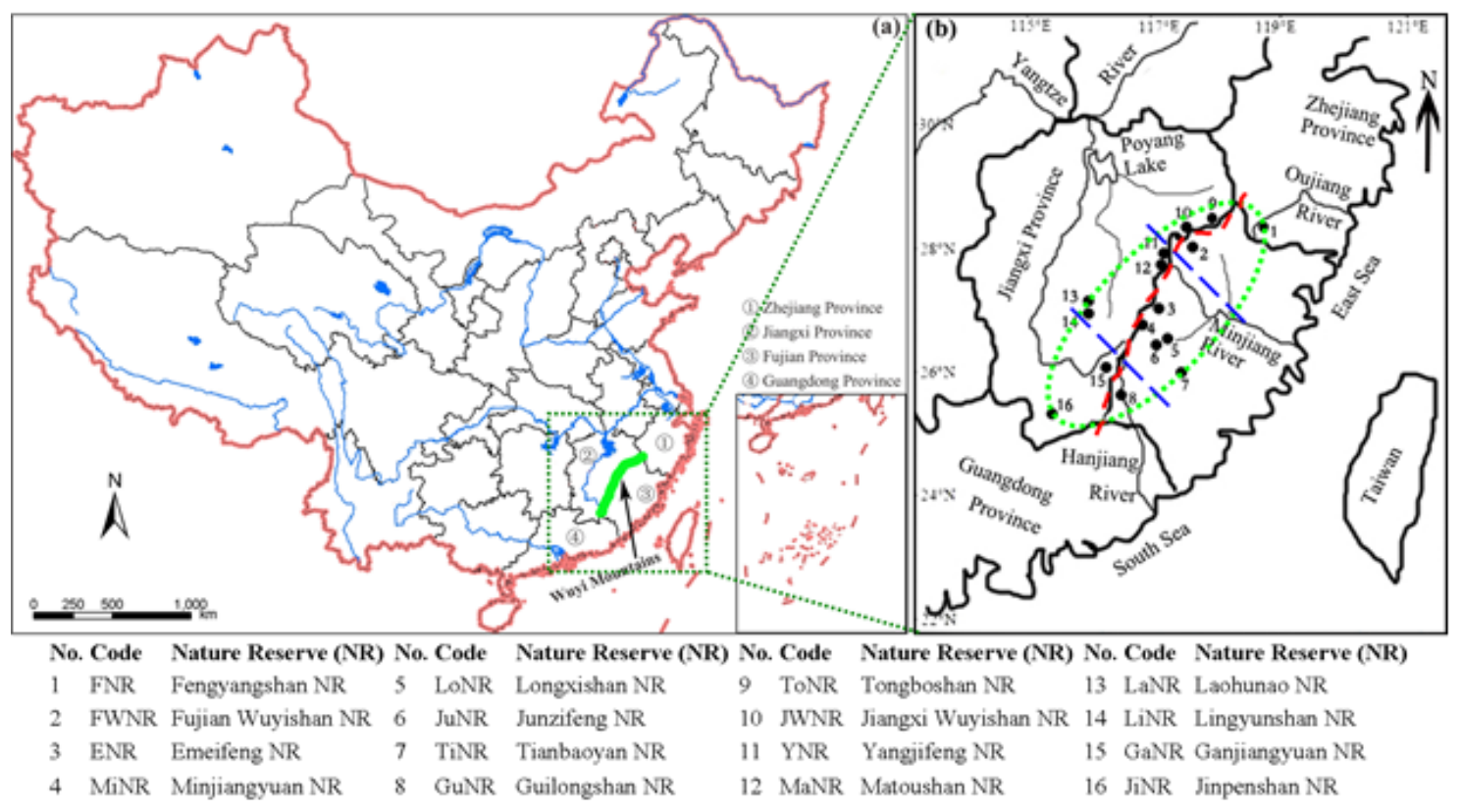

Figure 1. Maps showing the locations of Wuyi Mountains (a) and 16 nature reserves (b). In the map b, the Wuyi Mountains (the yellow elliptical region) is divided into two areas (west slope and east slope) by a dotted red line and three districts (north section, middle section and south section) by two blue broken lines

The 16 NRs are evenly located in the east and west slopes of the Wuyi Mountains, and lie on the north, middle and south sections of the mountain range (Fig. 1b). And the basic information of the 16 NRs was given in (Table 1).

Almost all of the rivers in those NRs were characterized by shallow water depths, surrounding by mountains, narrow channel widths and relatively fast currents flowing over boulder substrate. The main rivers in NRs are: Shiwudugang River in ToNR; Yanshanhe River in JWNR; Luxihe River, Luotanghe River and Guiganghe River in YNR; Matoushanhe River, Douhuanhe River in MaNR; Guganghe River in LaNR; Linchihe River in LiNR; Shiliaohe River, Pantianhe River in GaNR; Daqiaohe River in JiNR; Haohe River in FNR; Futunxi River, Chongyangxi River in FWNR; Shanxi 
River, Puxi River and Yongxingqu River in ENR; Chuxi River, Suixi River in MiNR; Yujiaxi River, Lishanxi River and Weixi River in LoNR; Xiafangxi River, Xiayangxi River, Chenglanxi River and Zhushexi River in JuNR; Sukengxi River, Guixi River and Shushaxi River in TiNR; Tongfanghe River, Jinxihe River and Chenlianhe River in GuNR.

Table 1. Basic information of 16 nature reserves in the Wuyi Mountains, China. The nature reserve codes are the same as those in Figure 1

\begin{tabular}{|c|c|c|c|c|c|c|}
\hline $\begin{array}{l}\text { Nature } \\
\text { reserve }\end{array}$ & $\begin{array}{c}\text { Geographical } \\
\text { coordinate }\end{array}$ & $\begin{array}{l}\text { Area } \\
\left(\mathbf{k m}^{2}\right)\end{array}$ & Protection object & $\begin{array}{c}\text { Protection } \\
\text { type }\end{array}$ & \begin{tabular}{|c|}
$\begin{array}{c}\text { Protection } \\
\text { level }\end{array}$ \\
\end{tabular} & $\begin{array}{c}\text { Stream } \\
\text { basin }\end{array}$ \\
\hline ToNR & $\begin{array}{c}118^{\circ} 12^{\prime}-118^{\circ} 21^{\prime} \mathrm{E} \\
28^{\circ} 03^{\prime}-28^{\circ} 15^{\prime} \mathrm{N}\end{array}$ & 108 & $\begin{array}{c}\text { Mid-subtropical broadleaved } \\
\text { evergreen forests }\end{array}$ & $\begin{array}{c}\text { Forest } \\
\text { ecological }\end{array}$ & National & \multirow{8}{*}{$\begin{array}{l}\text { Yangtze } \\
\text { River }\end{array}$} \\
\hline JWNR & $\begin{array}{c}117^{\circ} 39^{\prime}-117^{\circ} 55^{\prime} \mathrm{E} \\
27^{\circ} 48^{\prime}-28^{\circ} 00^{\prime} \mathrm{N}\end{array}$ & 160.07 & $\begin{array}{l}\text { Mid-subtropical broadleaved } \\
\text { evergreen forests, rare animals } \\
\text { and plants }\end{array}$ & $\begin{array}{l}\text { Forest } \\
\text { ecological }\end{array}$ & National & \\
\hline YNR & $\begin{array}{l}117^{\circ} 11^{\prime}-117^{\circ} 28^{\prime} \mathrm{E} \\
27^{\circ} 51^{\prime}-28^{\circ} 02^{\prime} \mathrm{N}\end{array}$ & 109.46 & $\begin{array}{l}\text { Amphibian, subtropical } \\
\text { broadleaved evergreen forests }\end{array}$ & Wildlife & National & \\
\hline MaNR & $\begin{array}{c}117^{\circ} 10^{\prime}-117^{\circ} 18^{\prime} \mathrm{E} \\
27^{\circ} 43^{\prime}-27^{\circ} 52^{\prime} \mathrm{N} \\
\end{array}$ & 138.67 & $\begin{array}{c}\text { Subtropical broadleaved } \\
\text { evergreen forests, rare plants }\end{array}$ & $\begin{array}{c}\text { Forest } \\
\text { ecological } \\
\end{array}$ & National & \\
\hline LaNR & $\begin{array}{c}115^{\circ} 51^{\prime}-116^{\circ} 03^{\prime} \mathrm{E} \\
26^{\circ} 58^{\prime}-27^{\circ} 17^{\prime} \mathrm{N}\end{array}$ & 220 & South China tiger and habitats & Wildlife & Provincial & \\
\hline LiNR & $\begin{array}{l}115^{\circ} 50^{\prime}-116^{\circ} 01^{\prime} \mathrm{E} \\
26^{\circ} 50^{\prime}-27^{\circ} 02^{\prime} \mathrm{N}\end{array}$ & 113.43 & $\begin{array}{c}\text { Subtropical broadleaved } \\
\text { evergreen forests }\end{array}$ & $\begin{array}{c}\text { Forest } \\
\text { ecological }\end{array}$ & Provincial & \\
\hline GaNR & $\begin{array}{c}116^{\circ} 03^{\prime}-116^{\circ} 20^{\prime} \mathrm{E} \\
25^{\circ} 52^{\prime}-26^{\circ} 06^{\prime} \mathrm{N} \\
\end{array}$ & 161.01 & $\begin{array}{c}\text { Mid-subtropical broadleaved } \\
\text { evergreen forests }\end{array}$ & $\begin{array}{c}\text { Forest } \\
\text { ecological }\end{array}$ & National & \\
\hline JiNR & $\begin{array}{l}115^{\circ} 10^{\prime}-115^{\circ} 15^{\prime} \mathrm{E} \\
25^{\circ} 11^{\prime}-25^{\circ} 15^{\prime} \mathrm{N}\end{array}$ & 37.12 & $\begin{array}{c}\text { Subtropical broadleaved } \\
\text { evergreen forests }\end{array}$ & $\begin{array}{c}\text { Forest } \\
\text { ecological }\end{array}$ & County & \\
\hline FNR & $\begin{array}{c}119^{\circ} 03^{\prime}-119^{\circ} 15^{\prime} \mathrm{E} \\
27^{\circ} 40^{\prime}-27^{\circ} 58^{\prime} \mathrm{N}\end{array}$ & 260.52 & $\begin{array}{l}\text { forest ecosystems, rare animals } \\
\text { and plants }\end{array}$ & $\begin{array}{c}\text { Forest } \\
\text { ecological }\end{array}$ & National & $\begin{array}{l}\text { Oujiang } \\
\text { River }\end{array}$ \\
\hline FWNR & $\begin{array}{c}117^{\circ} 27^{\prime}-117^{\circ} 51^{\prime} \mathrm{E} \\
27^{\circ} 33^{\prime}-27^{\circ} 54^{\prime} \mathrm{N} \\
\end{array}$ & 565.27 & $\begin{array}{c}\text { Mid-subtropical forest } \\
\text { ecosystems }\end{array}$ & $\begin{array}{c}\text { Forest } \\
\text { ecological }\end{array}$ & National & \multirow{6}{*}{$\begin{array}{l}\text { Minjiang } \\
\text { River }\end{array}$} \\
\hline ENR & $\begin{array}{c}117^{\circ} 01^{\prime}-117^{\circ} 10^{\prime} \mathrm{E} \\
26^{\circ} 52^{\prime}-27^{\circ} 06^{\prime} \mathrm{N}\end{array}$ & 103 & $\begin{array}{c}\text { Rare birds, Isoetes orientalis and } \\
\text { habitats, broadleaved deciduous } \\
\text { forests of Fagus lucida }\end{array}$ & Wildlife & Provincial & \\
\hline MiNR & $\begin{array}{c}116^{\circ} 46^{\prime}-116^{\circ} 59^{\prime} \mathrm{E} \\
26^{\circ} 35^{\prime}-26^{\circ} 49^{\prime} \mathrm{N}\end{array}$ & 130.22 & $\begin{array}{l}\text { Native populations of } \\
\text { Bretschneidera sinensis and } \\
\text { Taxus chinensis var mairei, } \\
\text { unique biological community, } \\
\text { forest vegetation of the } \\
\text { Mingjiang river source }\end{array}$ & Wildlife & National & \\
\hline LoNR & $\begin{array}{c}117^{\circ} 13^{\prime}-117^{\circ} 21^{\prime} \mathrm{E} \\
26^{\circ} 28^{\prime}-26^{\circ} 37^{\prime} \mathrm{N}\end{array}$ & 156.93 & $\begin{array}{c}\text { Mid-subtropical forest } \\
\text { ecosystems, rare animals and } \\
\text { plants }\end{array}$ & $\begin{array}{c}\text { Forest } \\
\text { ecological }\end{array}$ & National & \\
\hline JuNR & $\begin{array}{c}116^{\circ} 47^{\prime}-117^{\circ} 31^{\prime} \mathrm{E} \\
26^{\circ} 19^{\prime}-26^{\circ} 39^{\prime} \mathrm{N}\end{array}$ & 180.61 & $\begin{array}{l}\text { Mid-subtropical broadleaved } \\
\text { evergreen forests, Taxus } \\
\text { chinensis var mairei }\end{array}$ & $\begin{array}{c}\text { Forest } \\
\text { ecological }\end{array}$ & National & \\
\hline TiNR & $\begin{array}{c}117^{\circ} 28^{\prime}-117^{\circ} 35^{\prime} \mathrm{E} \\
25^{\circ} 50^{\prime}-26^{\circ} 01^{\prime} \mathrm{N}\end{array}$ & 110.15 & $\begin{array}{c}\text { Mid-subtropical broadleaved } \\
\text { evergreen forests, wild } \\
\text { orchidaceae, Tsuga longibracteata } \\
\text { forest, Rhododendron simiarum } \\
\text { forest, Sphagnum bog } \\
\end{array}$ & $\begin{array}{c}\text { Forest } \\
\text { ecological }\end{array}$ & National & \\
\hline GuNR & $\begin{array}{c}116^{\circ} 02^{\prime}-116^{\circ} 40^{\prime} \mathrm{E} \\
25^{\circ} 02^{\prime}-26^{\circ} 02^{\prime} \mathrm{N}\end{array}$ & 57.68 & $\begin{array}{l}\text { Mid-subtropical forest } \\
\text { ecosystems }\end{array}$ & $\begin{array}{c}\text { Forest } \\
\text { ecological }\end{array}$ & Provincial & $\begin{array}{c}\text { Hanjiang } \\
\text { River }\end{array}$ \\
\hline
\end{tabular}


At present, many researchers have investigated biodiversity and distribution of the bryophytes, ferns, vascular plants, freshwater crabs and reptiles in the Wuyi Mountains (Guan, 2006; Li et al., 2006; Ye et al., 2007; Zhu, 2010; Cheng et al., 2011; Shi et al., 2012). Although many scholars have studied the biodiversity and composition of fish and published many related articles, the diversity of fish species in mountainous areas has not been comprehensively studied. In order to systematically understand the species diversity of fish in Wuyi Mountain, it is very important to comprehensively analyze the spatial distribution and composition of fish in Wuyi Mountain. The objectives of this study are to: (1) to describe the species composition and diversity of fish in 16 nature reserves; (2) analyse the biodiversity and relationship of fish in 16 nature reserves.

\section{Materials and methods}

Many papers have studied on the fish in 16 nature reserves, which is A good compilation opportunity to make a fish species list to research the Wuyi mountain's biodiversity. (Anonymity, 1981, 1997; Lin, 2002, 2004; Lin et al., 2005; Liu and Fu, 2006; Guo et al., 2011; Hu et al., 2011, 2015, 2018; Liu et al., 2012; Zeng et al., 2013; Li et al., 2015; Miao et al., 2016; Zhu et al., 2017). By re-analyze and summarize the research results of fish species diversity in nature reserves, biodiversity information can be obtained.

Nowadays, the G-F index is an important method for studying fish diversity, which is usually used to analyze species diversity of birds and mammals (Jiang and Ji, 1999; Yu et al., 2005; Li and Wu, 2006; Cai et al., 2009; Huang and Liu, 2011). Computing the diversity indexes at the genus level (G-index) and the family level (F-index); then to calculate the ratio of G-index and F-index as G-F index, the values can be either positive or negative.

(1) F-index:

$$
D_{F}=-\sum_{k=1}^{m} D_{F k}=-\sum_{k=1}^{m} \sum_{i=1}^{n} p_{i} \ln p i
$$

where $\mathrm{n}=$ the number of genera in family $\mathrm{k}, \mathrm{pi}=\mathrm{Ski} / \mathrm{Sk}, \mathrm{Ski}=$ the number of species in genus $\mathrm{i}, \mathrm{Sk}=$ the number of species in family $\mathrm{k}, \mathrm{m}=$ the total number of families in the class.

(2) G-index:

$$
D_{G}=-\sum_{j=1}^{p} q_{j} \ln q_{j}
$$

where $q j=S j / S, S j=$ the number of species in genus $\mathrm{j}, \mathrm{S}=$ the total number of species in the class, $\mathrm{p}=$ the total number of genus in the class.

(3) G-F index:

$$
\mathrm{D}_{\mathrm{G}-\mathrm{F}}=1-\mathrm{D}_{\mathrm{G}} / \mathrm{D}_{\mathrm{F}}
$$


Cluster analysis is often used to study the distribution of fish species and other community ecological problems. (Yin et al., 2016). A dataset containing all species from each site has been established to enable similarity measurements based on the presence (1) or absence (0) of each species from each site. (Huang et al., 2013). Pairwise similarities among all sites were computed in order to create a similarity coefficient matrix. The hierarchical cluster, furthest-neighbour method with pearson correlation was used for cluster analysis based on the matrix. All analyses were performed using SPSS 13.0 software.

\section{Results}

\section{Composition of fish species}

126 freshwater fish species (see Appendix 1) in the 16 NRs were recorded, belonging to five orders and 17 families. Cypriniformes (comprised of four families and 88 species, $69.8 \%$ of total species) was the dominant order followed by Siluriformes (five families and 21 species, 16.7\%) and Perciformes (five families and 13 species, 10.3\%), while Anguilliformes and Synbranchiformes were represented by two species respectively (Table 2). Species of family Cyprinidae comprised $51.6 \%$ of the total species richness and classified into 10 subfamilies (i.e. Danioninae, Leuciscinae, Cultrinae, Xenocyprinae, Hypophthalmichthyinae, Acheilognathinae, Gobioninae, Gobiobotinae, Cyprininae and Barbinae).

Table 2. Fish diversity indices in different districts of the Wuyi Mountains, China

\begin{tabular}{c|c|c|c|c}
\hline District & G-index & F-index & G-F index & Species richness \\
\hline West slope & 1.6628 & 2.3287 & 0.2860 & 77 \\
East slope & 1.8365 & 2.9620 & 0.3800 & 100 \\
North section & 1.6261 & 2.9232 & 0.4437 & 91 \\
Middle section & 1.7948 & 3.0614 & 0.4137 & 101 \\
South section & 1.3090 & 1.5061 & 0.1309 & 30 \\
\hline
\end{tabular}

Overall, 72 species (57.1\% of the total species) are endemic to China, belonging to 11 families. Cyprinidae is the dominant family of endemic species (33 species) and the subdominant family was Balitoridae (16 species), and Bagridae (11 species), while Cobitidae, Amblycipitidae, Percichthyidae, Gobiidae, Sisoridae, Siluridae, Ondontobutidae and Osphronemidae were represented by only one or two species respectively (see Appendix).

\section{Spatial variation of fish species diversity}

Among the 16 NRs, eight reserves (including ToNR, JWNR, YNR, MaNR, LaNR, LiNR, GaNR and JiNR) are located in the west slope of the Wuyi Mountains, while other reserves (FNR, FWNR, ENR, MiNR, LoNR, JuNR, TiNR and GuNR) lie on the east slope of the mountain range. In addition, four reserves (ToNR, JWNR, FNR and FWNR) are located in the north section of the Wuyi Mountains, nine reserves (YNR, MaNR, LaNR, LiNR, ENR, MiNR, LoNR, JuNR and TiNR) in the middle section of 
the mountain range, and three reserves (GaNR, JiNR and GuNR) in the south section of the mountain range (Fig. $1 b$ ).

A greater number of species (average: 42 vs. 21) and endemic species (19 vs. 11) were recorded from the east slope of the Wuyi Mountains compared to the west slope of the mountain range (Fig. 2). And the number of species and endemic species from the north section of the Wuyi Mountains was the largest (average: 36 and 20), followed by the middle section of the mountain range (35 and 15), while the average species number and endemic species number in the south section of the mountain range were only 15 and 8, respectively (Fig. 3).

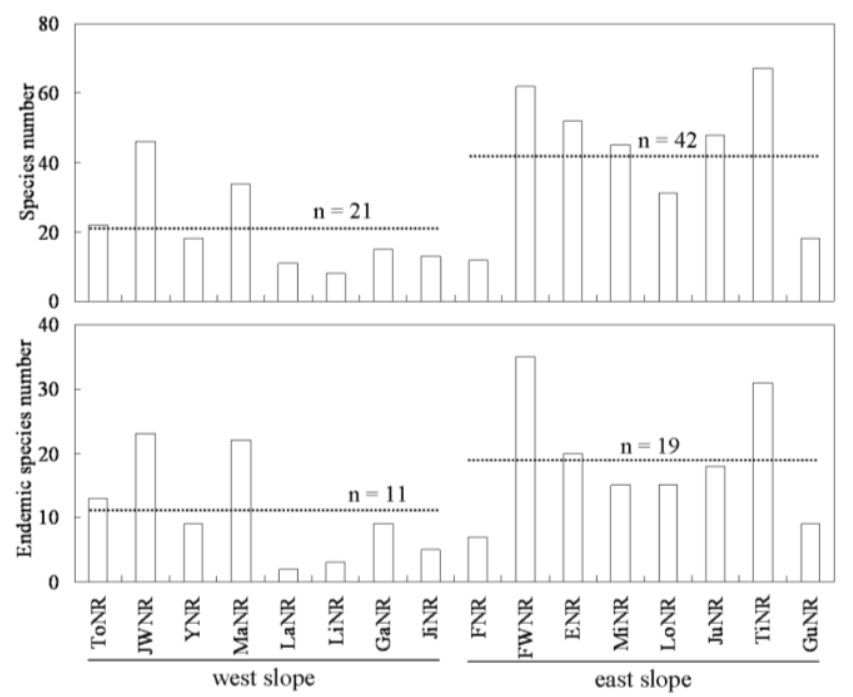

Figure 2. Species and endemic species richness in the west and east slopes of Wuyi Mountains, China ( $n=$ average number of fish species). The nature reserve codes are the same as those in Figure 1



Figure 3. Species and endemic species richness in the north, middle and south sections of Wuyi Mountains, China ( $n=$ average number of fish species). The nature reserve codes are the same as those in Figure 1 
In addition, greater values of F-index, G-index and G-F index were also obtained from the east slope of the Wuyi Mountains compared to the west slope of the mountain range. And F-index, G-index and G-F index in the north section and middle section of the mountain range were similar, while the F-index, G-index and G-F index in the south section of the mountain range were the lowest (Table 2). The species richness of north section, middle section have similarity. While the species richness of south section were the lowest, and the east slope's richness is higher than west slope.

\section{Clustering analysis}

By studying the presence-absence data of fish in each nature reserve in Wuyi Mountains, the fish fauna can be divided into four regions (Fig. 4). The first region included MiNR, ENR, JuNR, TiNR, FWNR and LoNR, their mountain streams belong to the Minjiang River Basin. The second and third regions were FNR and GuNR, their mountain streams flow into the Oujiang River or the Hanjiang River respectively. The fourth region included JWNR, LaNR, ToNR, JiNR, YNR, GaNR, LiNR and MaNR, their mountain streams belong to the Poyang Lake Basin which flows into the Yangtze River. In addition, according to the result of cluster analysis, 16 nature reserves can be divided into two faunas, the east slope and west slope of the Wuyi Mountains.

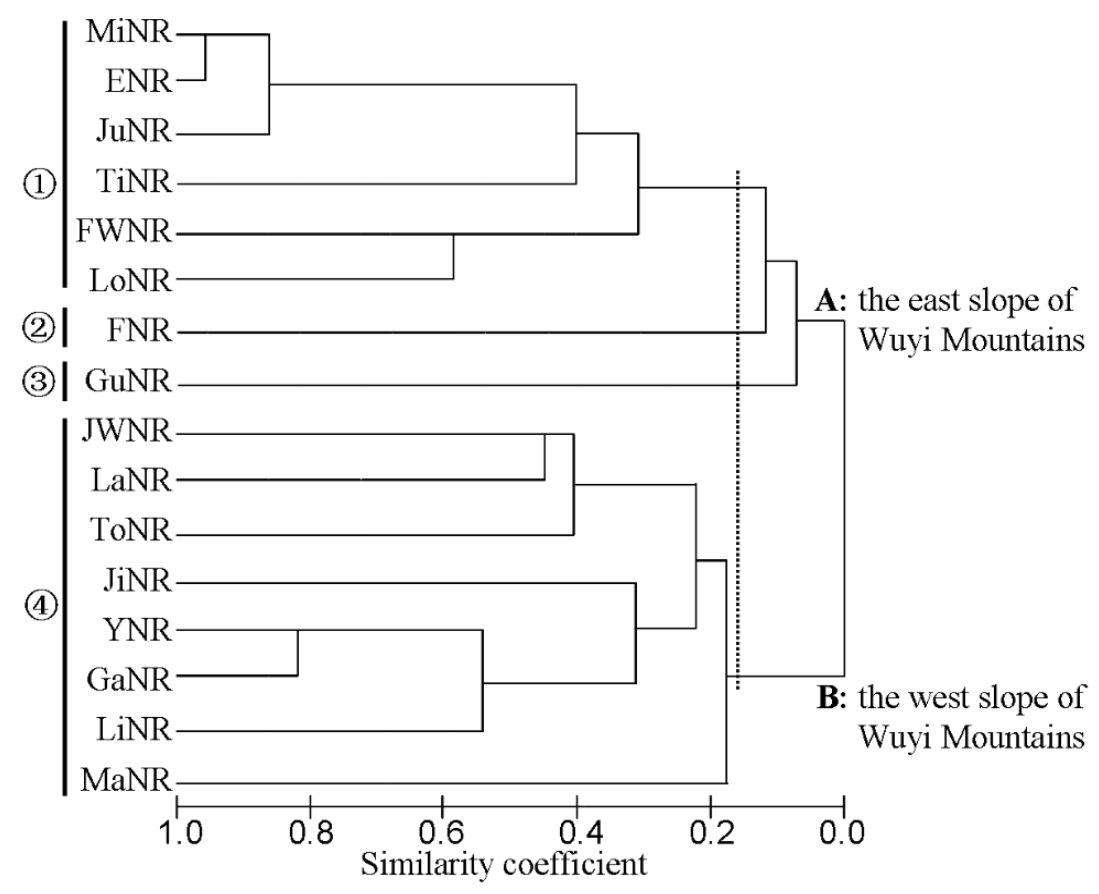

Figure 4. The classification of 16 nature reserves in the Wuyi Mountains, China. 1: Minjiang River System; 2: Oujiang River System; 3: Hanjiang River System; 4: Yangtze River System. The nature reserve codes are the same as those in Figure 1

\section{Discussion}

\section{Characters of fish species diversity}

A total of 1323 species and 877 endemic species of freshwater fish had been reported in China (Xing et al., 2016). The results of the existing studies on the 16 nature reserves in the Wuyi Mountains showed that a total of 126 species $(9.5 \%$ of all freshwater fish 
species in China) and 72 endemic species (8.2\% of all freshwater endemic species in China) were found to be distributed in mountain streams. Several endangered (Anguilla marmorata, Acrossocheilus wenchowensis, Liobagrus marginatus and Pseudobagrus medianalis) and vulnerable species (Leptobotia elongate, Siniperca obscura and Siniperca roulei) were found in the Wuyi Mountains, and most of them are endemic to China. The coldwater and endemic species (e.g. Rhynchocypris oxycephalus) had also been found in the mountain range. In addition, endemic species of families Balitoridae and Gobiidae, the sucker structure under their bodies allows them to attach to the boundary layer matrix created by water flow at the bottom of the water so as to survive in mountain streams, and they were found in most nature reserves within the mountain range. We can conclude that the diversity and conservation of freshwater fish species (especially endemic species) are highly dependent on the mountain stream environment of Wuyi Mountains. The stability and low disturbance of habitats (such as the introduction of less exotic species) may be the reason for the collection of rich species and endemic species in the mountain range. First-third streams are widely distributed in 16 nature reserves in Wuyi Mountains. Temperatures in the mountains also rarely reach $20{ }^{\circ} \mathrm{C}$ in summer because of the high forest coverage rates in the riparian areas of the mountain range. And the content of dissolved oxygen is high, which provides suitable living conditions for these fishes (Hu et al., 2011, 2015, 2018; Guo et al., 2011; Huang et al., 2013).

As environments be different, the species composition of fish also change (Cowx, 1994). The comparison of species number, endemic species number and values of Findex, G-index and G-F index between the west and east slopes of Wuyi Mountains showed that there was a higher fish species diversity in the east slope. And among the three districts (i.e. the north, middle and south sections of Wuyi Mountains), fish species diversity was highest at the north section, good at the middle section and lowest at the south section (Fu et al., 2003; Jang et al., 2003; Yin et al., 2016; Song et al., 2017). Existing studies for bryophytes, ferns, vascular plants, freshwater crabs and reptiles in the Wuyi Mountains showed the similar variation tendency (Guan, 2006; Li et al., 2006; Ye et al., 2007; Zhu, 2010; Cheng et al., 2011; Shi et al., 2012).

\section{Current threats}

The biodiversity of the Wuyi Mountains is threatened by a wide range of anthropogenic activities, including overexploitation and habitat change. Sedentary species are also affected by hydrological alterations and tend to redistribute along the river gradient (Araújo et al., 2013). Habitat alteration and destruction as the major cause of most extinctions of freshwater fishes (Thomas., 1994). Despite being prohibited by law, unsustainable and short-term fishing practices like electro-fishing are rampant throughout China (Zhao et al., 2015), causing great damage to fish resources in various regions of the country. In the mountain range, some people catch fish for food on streams using electro-fishing, rotenone or other poisons (Guo et al., 2011; Hu et al., 2011, 2015, 2018; Liu et al., 2012; Zeng et al., 2013; Miao et al., 2016). This kind of fishing had led to over-fishing which had also caused a rapid decline in fish biodiversity.

In recent decades, agricultural activity, increased demand for drinking water, and the construction of multi-purpose dams, artificial reservoirs, and levees and weirs have led to major changes in China's streams and rivers (Fu et al., 2003). In the mountain range, 
dams had been built on streams in most of nature reserves (Guo et al., 2011; Hu et al., 2011, 2015, 2018; Liu et al., 2012; Zeng et al., 2013; Miao et al., 2016). Streams with faster flow rates often slow down and transformed into wide and slow-flowing streams. These factors have impeded the efficient migration of species migrating between different river habitats. This variation means that these organisms will be replaced by species which adapted to slower streams (Hu et al., 2009). Anthropogenic hydrological changes have had a negative affect the biodiversity of fish greatly.

\section{Conservation recommendations}

The Chinese government and environmental protection agencies have taken measures to protect the biodiversity of fish in these nature reserves, but these measures have not been effective. Changes brought by human activities and facilities accelerate the deterioration of mountain river environment, so the protection measures for fish biodiversity need to be improved and strengthened.

First, an in-depth understanding of both large-scale species richness patterns and endemism patterns is an essential basis for the conservation of freshwater fish resources (Oberdorff et al., 1999). A more comprehensive assessment of the status of freshwater fish stocks can be achieved using this method. But the data need to be updated in time for the protection agency to formulate the correct protection measures. Therefore, the overall freshwater fish resource assessment of Wuyi Mountains needs to be carried out as soon as possible. In addition, the government should establish a comprehensive database to update the status and information of species.

Second, the development of effective management measures is the first step to protect the species diversity and endemism of Wuyi mountain's fish, which will effectively control and manage the integrity of the fish life cycle and the maintenance of population quantity in the river. The government needs to improve the construction of fish passage facilities so that fish can migrate smoothly between rivers and breeding (Jang et al., 2003).

Third, Penalties for illegal activities should be increased in the mountain area of Wuyi Mountains, so as to better protect fish diversity and resource quantity better. At the same time, fishing must be prohibited in mountainous areas, especially the use of poison such as rotenone. Draft legislation on wildlife buffer zones in the Wuyi Mountains, promoting sustainable agriculture to prevent pollution and limit fishing activities (Jang et al., 2003).

\section{Conclusion}

These results indicate that the freshwater fish species diversity is closely related to the environment of Wuyi mountain streams, especially for the endemic species. However, fish biodiversity in the mountain range is facing numerous threats, such as over-exploitation and habitat alteration. Thus, the conservation of fish biodiversity has become urgent, and an integrated management plan should be developed and effectively implemented.

Acknowledgements. This work was supported by the National Natural Science Foundation of China [31360118] and Innovation and Entrepreneurship Fund of Nanchang University [2018270].

Conflicts of interests. The authors declare that they have no conflicts of interests. 


\section{REFERENCES}

[1] Araújo, E. S., Marques, E. E., Freitas, I. S., Neuberger, A. L., Fernandes, R., Pelicice, F. M. (2013): Changes in distance decay relationships after river regulation: similarity among fish assemblages in a large Amazonian river. - Ecology of Freshwater Fish 22: 543-552.

[2] Anonymity (1981): Report of Scientific Survey on Fengyangshan Nature Reserve. - Zhejiang Science and Technology Press, Lishui.

[3] Anonymity (1997): Report of Scientific Survey on Longxishan Nature Reserve. - Fujian Science and Technology Press, Fuzhou.

[4] Cai, D. S., Zhao, X. G., Zhu, Y., Zhou, J., Shi, J., Han, Y. Q. (2009): Investigation on fish resources and analysis of species diversity in Lijiang River. - Journal of Guangxi Normal University 27(2): 130-136.

[5] Chen, Y. L., Zhang, Q. J., Xu, H. (2009): Reptilian Fauna and Zoogeographic Division of Fujian Province. - Sichuan Journal of Zoology 28(6): 928-932.

[6] Cheng, S. L., Yuan, R. B., Mao, Y. X. (2011): Reptilian geographical distribution and G-F index in Wuyi Mountains. - Resources and Environment in the Yangtze Basin 20(Z1): 22-29.

[7] Cowx, I. G., (1994): Strategic Approach to Fishery Rehabilitation. Rehabilitation of Freshwater Fisheries. - Fishing News Books. Blackwell Science, Oxford, pp. 3-10.

[8] Fu, C. Z., Wu, J. H., Chen, J. K., Wu, Q. H., Lei, G. C. (2003): Freshwater fish biodiversity in the Yangtze River basin of China: patterns, threats and conservation. - Biodiversity and Conservation 12: 1649-1685.

[9] Guan, S. R. (2016): Studies on Biodiversity of Bryophytes in Wuyi Mountain, China. Hangzhou Normal Univ., Hangzhou.

[10] Guo, S., Wu, Z. Q., Hu, M. L., Zhou, H. M. Li, Q. (2011): Preliminary survey of fish Yangijifeng Nature Reserve, Jiangxi Province. - Journal of Hydroecology 32(3): 142-144.

[11] Hu, M. L., Wu, Z. Q., Liu, Y. L., (2009): The fish fauna of mountain streams in the Guanshan National Nature Reserve, Jiangxi, China. - Environmental Biology of Fishes 86: 23-27.

[12] Hu, M. L., Wu, Z. Q., Li, Q., Huang, L. L. (2011): Preliminary research on fish species diversity of Ganjiangyuan Nature Reserve in Jiangxi Province. - Sichuan Journal of Zoology 30(3): 467-470.

[13] Hu, M. L., Wu, Z. Q., Ouyang, S. ,Wu, X. P. (2015): Ichthyofaunal diversity of mountain streams in the Tongboshan Nature Reserve, China. - African Journal of Agricultural Research 10(18): 1965-1970.

[14] Hu, M. L., Wang, C. Y., Zhang, X. Y., Yuan, R. B., Zhang, A. F., Wu, L. Z. Jian, S. Q. (2018): Fish species abundance and distribution in Wuyishan National Nature Reserve, Jiangxi Province, China. - eco mont-Journal on Protected Mountain Areas Research and Management 10(2): 9-16.

[15] Huang, L. L., Wu, Z. Q., Li, J. H. (2013): Fish fauna, biogeography and conservation of freshwater fish in Poyang Lake Basin, China. - Environmental Biology of Fishes 96: 12291243.

[16] Huang, Z. H., Liu, B. (2011): G-F index of reptiles in Jiangxi Province. - Journal of Jinggangshan University 32(3): 124-127.

[17] Jang, M. H., Lucas, M. C., Joo, G. J. (2003): The fish fauna of mountain streams in South Korean national parks and its significance to conservation of regional freshwater fish biodiversity. - Biological Conservation 114: 115-126.

[18] Jiang, Z. G., Ji, L. Q. (1999): Avian-mammalian species diversity in nine representative sites in China. - Chinese Biodiversity 7(3): 61-66.

[19] Li, Y. M., Wu, X. B. (2006): Avian diversity in Wuhu City in summer and winter. - Chinese Journal of Applied Ecology 17(2): 269-274.

[20] Li, Z. J., Lin, P., Ye, W., Chen, L. Z., Qiu, L., Chen, S. B., Liu, C. D., He, J. Y., Dai, D. S., Li, L. (2006): Diversity connectivity of vascular plants from southern to northern Wuyi Mountains. - Progress in Natural Science 16(8): 959-964. 
[21] Li, Z. J., Chen, X. L., Liu, C. M., Jin, B. S. (2015): Research on Biodiversity in the Emeifeng Nature Reserve of Fujian. - Science Press, Beijing.

[22] Lin, P. (2002): Report of Scientific Survey on Tianbaoyan Nature Reserve of Fujian. Xiamen, Xiamen University Press, Xiamen.

[23] Lin, P. (2004): Report of scientific survey on Minjiangyuan Nature Reserve of Fujian. Xiamen, Xiamen University Press, Xiamen.

[24] Lin, P., Li, Z. J., Zhang, J. (2005): Report of Scientific Survey on Junzifeng Nature Reserve of Fujian. - Xiamen University Press, Xiamen.

[25] Liu, J. Q., Yang, Q., Xiao, G. R., Liu, C. M. (2012): Wuyi Mountain Biodiversity Research Information Platform, Fujian, China. - Science Press, Beijing [in Chinese].

[26] Liu, X. Z., Fu, Q. (2006): Scientific Survey and Study of Rare Phytocoenosium on the Matoushan Nature Reserve in Jiangxi Province. - China Forestry Press, Beijing.

[27] Miao, C., Zhu, Y. H., Yuan, R. B., Zou, Z. A. Hu, M. L., Shao, S. P., Yin, H., Yan, X. (2016): Fish species diversity in Jinpenshan Nature Reserve Zone, Jinagxi Province, in Summer. Chinese Journal of Fisheries 29(4): 28-32.

[28] Ministry of Ecology and Environment of the PRC (2016): Writing a Research Paper. http://www.mee.gov.cn/stbh/zrbhq/qgzrbuqml/201611/P02016112559865886359.pdf (accessed: 8 November 2016).

[29] Oberdorff, T., Lek, S., Guegan, J. F. (1999): Patterns of endemism in riverine fish of the Northern Hemisphere. - Ecology Letters 2: 75-81.

[30] Shi, L. B., Zhang, X. Y., Zou, J. X., Wang, Y., Liu, D. R., Zhu, C. C., Zhou, X. M. (2012): Distribution pattern of the freshwater crabs among Wuyi Mountains. - Journal of Nanchang University (Natural Science) 36(6): 556-561.

[31] Song, X. J., Tang, W. Q., Zhang, Y. (2017): Freshwater fish fauna and zoogeographical divisions in the Wuyi-Xianxialing Mountains of eastern China. - Biodiversity Science 25(12): 1331-1338.

[32] Thomas, C. D. (1994): Extinction, colonisation, and metapopulations: environmental tracking by rare species. - Conservation Biology. 8: 373-378.

[33] Xing, Y. C., Zhang, C. G., Fan, E. Y., Zhao, Y. H. (2016): Freshwater fishes of China: species richness, endemism, threatened species and conservation. - Diversity and Distributions 22: 358-370.

[34] Ye, W., Li, Z. J., Benito, C. T., Chang, Y., Chen, L. Z., He, J. Y., Liu, C. D. (2007): Study on the biodiversity of ferns from southern to northern Wuyi Mountains. - Journal of Xiamen University (Natural Science) 46(3): 431-437.

[35] Yin, C., Huang, L. L., Xu, L., Huang, J., Gao, M. H. (2016): Fish diversity in nature reserves of Jiangxi Province, China. - eco mont-Journal on Protected Mountain Areas Research 8(2): 33-42.

[36] Yu, X. D., Luo, T. H., Zhou, H. Z., (2005): Large-scale patterns in species diversity of fishes in the Yangtze River Basin. - Biodiversity Science 13(6): 473-495.

[37] Zeng, Z. G., Zeng, T., Chen, J. K., Jin, B. S. (2013): Preliminary investigation of fish resources of the Guilong Mountain Provincial Nature Reserve in Fujian Province in summer. - Journal of Fujian Fisheries 35(3): 167-174.

[38] Zhao, Y., Gozlan, R. E., Zhang, C. (2015): Current State of Freshwater Fisheries in China. In: Craig, J. F. (ed.) Freshwater Fisheries Ecology. John Wiley and Sons Ltd, Hoboken, NJ, pp. 221-229.

[39] Zhong, C. F.,(2004): Reptilian Fauna and Zoogeographic Division of Jiangxi Province. Sichuan Journal of Zoology 23(3): 222-229.

[40] Zhu, C. C., (2010): Zoogeographical Significance of Freshwater Crabs Family Potamidae and Parathelphusidae in Wuyi Mountain Region. - NanChang, Jiangxi, China.

[41] Zhu, Y. H., Yuan, R. B., Zou, Z. A., Hu, M. L. (2017): A study on fish diversity connectivity in western Wuyi Mountains. - Transactions of Oceanology and Limnology 5: 93-101. 


\section{APPENDIX 1}

The list of fish and distribution of 16 nature reserves in the Wuyi Mountains, China. The nature reserve codes are the same as those in Figure 1. (The presence-absence data of fish species are obtained from Anonymity, 1981, 1997; Lin, 2002, 2004; Lin et al., 2005; Liu and Fu, 2006; Guo et al., 2011; Hu et al., 2011, 2015, 2018; Liu et al., 2012; Zeng et al., 2013; Li et al., 2015; Miao et al., 2016; Zhu et al., 2017)

\begin{tabular}{|c|c|c|c|c|c|c|c|c|c|c|c|c|c|c|c|c|}
\hline Order/family/species & ToNR & JWNR & YNR & MaNR & LaNR & LiNR & GaNR & JiNR & FNR & FWNR & ENR & MiNR & LoNR & JuNR & TiNR & GuNR \\
\hline Anguilliformes & & & & & & & & & & & & & & & & \\
\hline Anguillidae & & & & & & & & & & & & & & & & \\
\hline Anguilla japonica & & & & & & & & & + & + & + & + & & + & + & + \\
\hline Anguilla marmorata & & & & & & & & & & + & + & & & + & + & \\
\hline Cypriniformes & & & & & & & & & & & & & & & & \\
\hline Cyprinidae & & & & & & & & & & & & & & & & \\
\hline Aphyocypris chinensis & & & & & & & & & & & + & + & & + & & \\
\hline Opsariichthys bidens & + & + & + & + & + & & + & + & + & + & + & + & + & + & + & + \\
\hline Zacco platypus & + & + & + & + & + & + & + & + & & + & + & + & + & + & + & + \\
\hline Ctenopharyngodon idella & & + & & & & & & & & & & & & & + & \\
\hline Elopichthys bambusa & & & & & & & & & & & + & + & & & & \\
\hline Mylopharyngodon piceus & & + & & & & & & & & & & & & & & \\
\hline Ochetobius elongatus & & & & & & & & & & & + & + & & + & & \\
\hline *Rhynchocypris oxycephalus & + & + & & + & & & & & & + & & & & & & \\
\hline Squaliobarbus curriculus & & & & & & & & & & & + & + & & & & \\
\hline Culter alburnus & + & & & & & & & & & & & & & & + & \\
\hline Cultrichthys erythropterus & + & & & & & & & & & + & & & + & & + & \\
\hline Hemiculter leucisculus & + & + & & & + & & & & & + & + & + & & + & + & \\
\hline *Megalobrama amblycephala & + & + & & & & & & & & & & & & & & \\
\hline Megalobrama terminalis & & & & & & & & & & & + & + & & & + & \\
\hline Pseudohemiculter dispar & & & & + & & & & & & + & + & + & + & + & & \\
\hline
\end{tabular}

APPLIED ECOLOGY AND ENVIRONMENTAL RESEARCH 17(5):11341-11357. http://www.aloki.hu • ISSN 15891623 (Print) • ISSN 17850037 (Online) DOI: http://dx.doi.org/10.15666/aeer/1705 1134111357

(c) 2019, ALÖKI Kft., Budapest, Hungary 
Pseudohemiculter hainanensis Pseudolaubuca sinensis

*Sinibrama macrops

*Distoechodon compressus

*Distoechodon tumirostris

Xenocypris argentea

Xenocypris davidi

Xenocypris microlepis

*Aristichthys nobilis

Hypophthalmichthys molitrix

Acheilognathus barbatulus

*Acheilognathus barbatus

Acheilognathus chankaensis

*Acheilognathus polylepis

Acheilognathus tonkinensis

*Rhodeus ocellatus

*Rhodeus sinensis

Abbottina rivularis

*Belligobio nummifer

*Gnathopogon imberbis

*Gnathopogon taeniellus

Hemibarbus labeo

Hemibarbus maculatus

*Huigobio chenhsienensis

*Huigobio chinssuensis

*Microphysogobio fukiensis

*Microphysogobio kiatingensis

*Pseudogobio vaillanti

Pseudorasbora parva

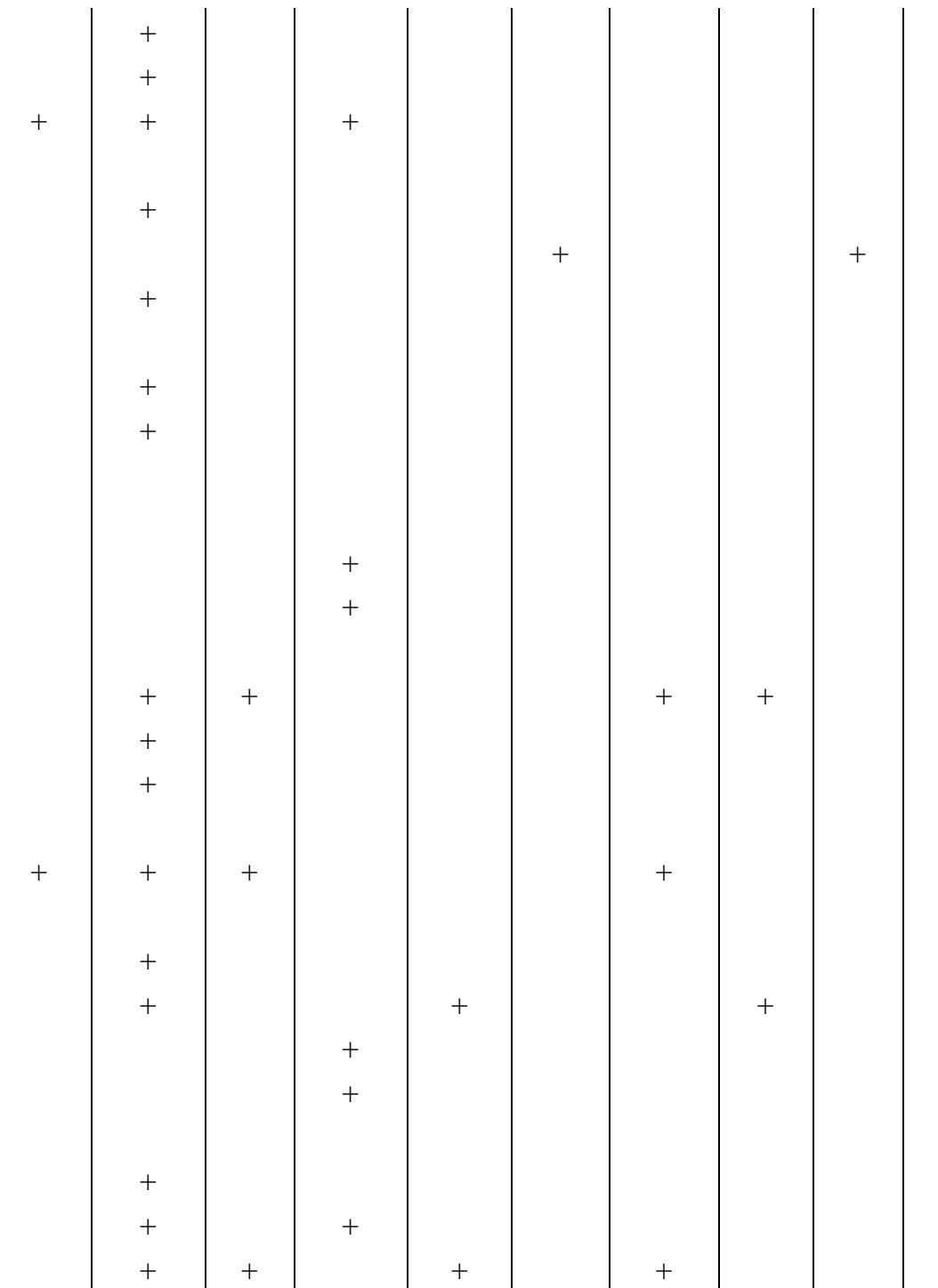


*Rhinogobio typus

*Sarcocheilichthys kiangsiensis Sarcocheilichthys nigripinnis

*Sarcocheilichthys parvus

* Sarcocheilichthys sinensis fukiensis

Saurogobio dabryi dabryi

*Saurogobio gracilicaudatus

Squalidus argentatus

*Squalidus wolterstorffi

*Gobiobotia longibarba

Carassius auratus auratus

Cyprinus carpio

*Acrossocheilus

hemispinus cinctus

*Acrossocheilus hemispinus hemispinus

*Acrossocheilus kreyenbergii

*Acrossocheilus labiatus

*Acrossocheilus parallens

*Acrossocheilus spinifer

*Acrossocheilus wenchowensis

*Onychostoma barbatula

Spinibarbus hollandi

Nemacheilidae

Schistura fasciolata

Cobitidae

Cobitis sinensis

Cobitis taenia

Misgurnus anguillicaudatus
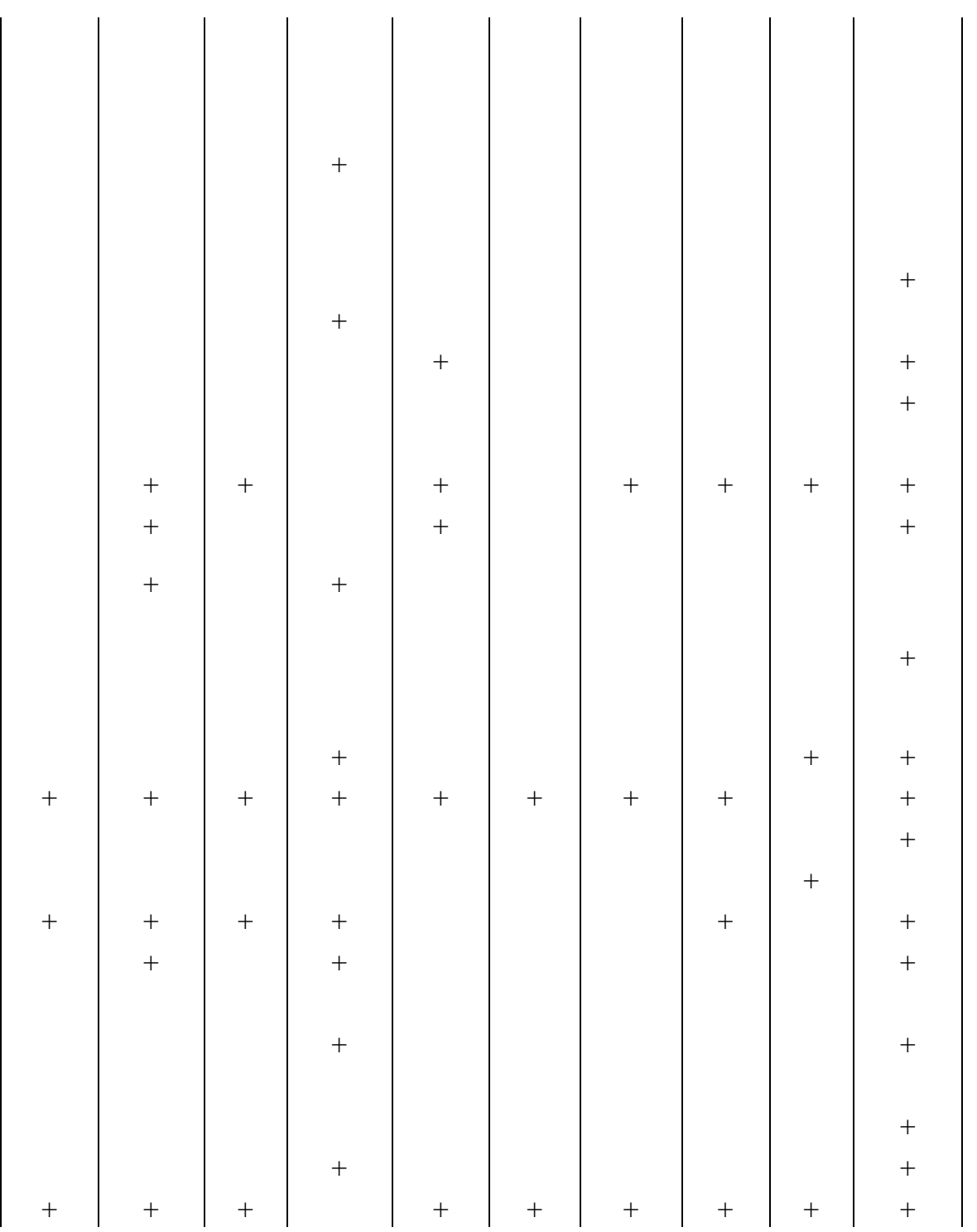

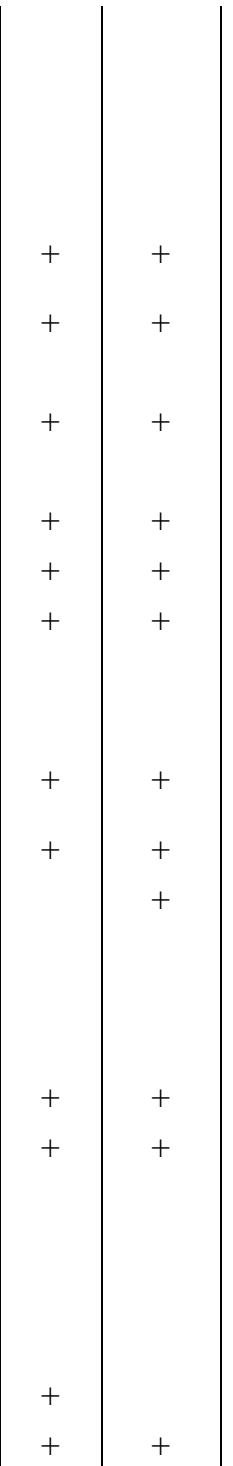

$+$

\begin{tabular}{l|l|l}
+ & + & \\
& & + \\
+ & & \\
+ & + & \\
+ & + & \\
+ & &
\end{tabular}

APPLIED ECOLOGY AND ENVIRONMENTAL RESEARCH 17(5):11341-11357.

http://www aloki.hu • ISSN 15891623 (Print) • ISSN 17850037 (Online)

DOI: http://dx doi org/10.15666/aeer/1705_1134111357

C) 2019, ALÖKI Kft., Budapest, Hungary 
*Leptobotia elongate

*Leptobotia tientaiensis compressicauda

Balitoridae

*Formosania davidi

*Formosania fascicauda

*Formosania lacustre

*Formosania stigmata

*Formosania tinkhami

Liniparhomaloptera disparis disparis

*Pseudogastromyzon changtingensis changtingensis

*Pseudogastromyzon changtingensis tungpeiensis

*Pseudogastromyzon cheni

*Pseudogastromyzon fangi

* Pseudogastromyzon fasciatus fasciatus

*Vanmanenia caldwelli

*Vanmanenia gymnetrus

*Vanmanenia pingchowensis

*Vanmanenia stenosoma

*Vanmanenia xinyiensis

*Hemimyzon formosanus

Siluriformes

Amblycipitidae

*Liobagrus anguillicauda

*Liobagrus marginatus

Sisoridae

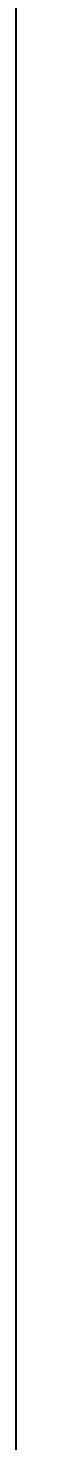

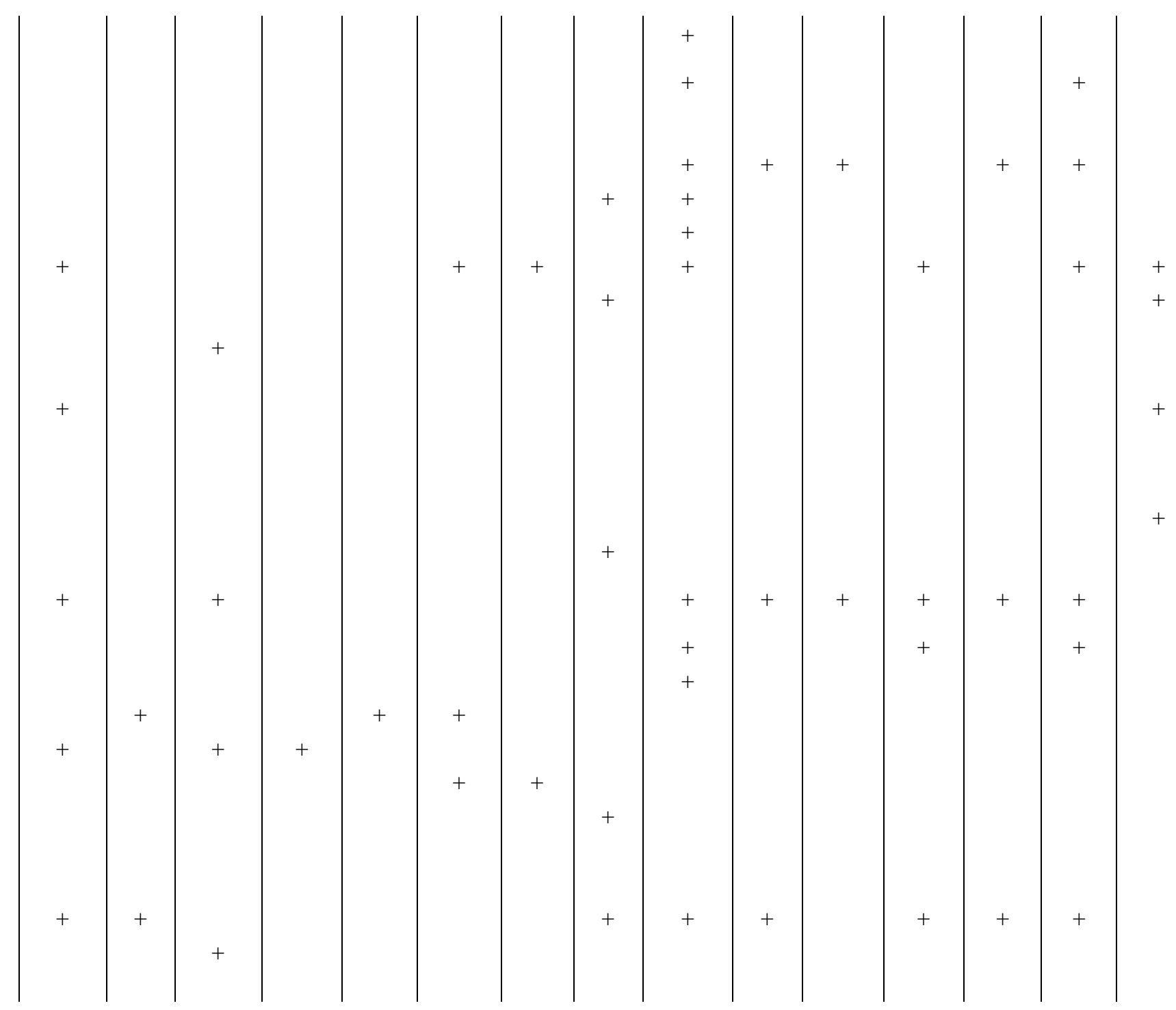

APPLIED ECOLOGY AND ENVIRONMENTAL RESEARCH 17(5):11341-11357. http://www.aloki.hu • ISSN 15891623 (Print) • ISSN 17850037 (Online)

DOI: http://dx doi org/10_15666/aeer/1705_1134111357 
*Glyptothorax fukiensis Glyptothorax sinensis

Siluridae

Silurus asotus

*Silurus meridionalis

Clariidae

Clarias fuscus

Bagridae

*Hemibagrus macropterus

*Leiocassis crassilabris

*Leiocassis tenuifurcatus

Pelteobagrus fulvidraco

*Pelteobagrus nitidus

Pelteobagrus vachellii

* Pseudobagrus adiposalis

*Pseudobagrus albomarginatus

*Pseudobagrus medianalis

* Pseudobagrus ondon

*Pseudobagrus taiwanensis

*Pseudobagrus tenuis

*Pseudobagrus truncatus

Pseudobagrus ussuriensis

Synbranchiformes

Synbranchidae

Monopterus albus

Mastacembelidae

Sinobdella sinensis

Perciformes

Percichthyidae
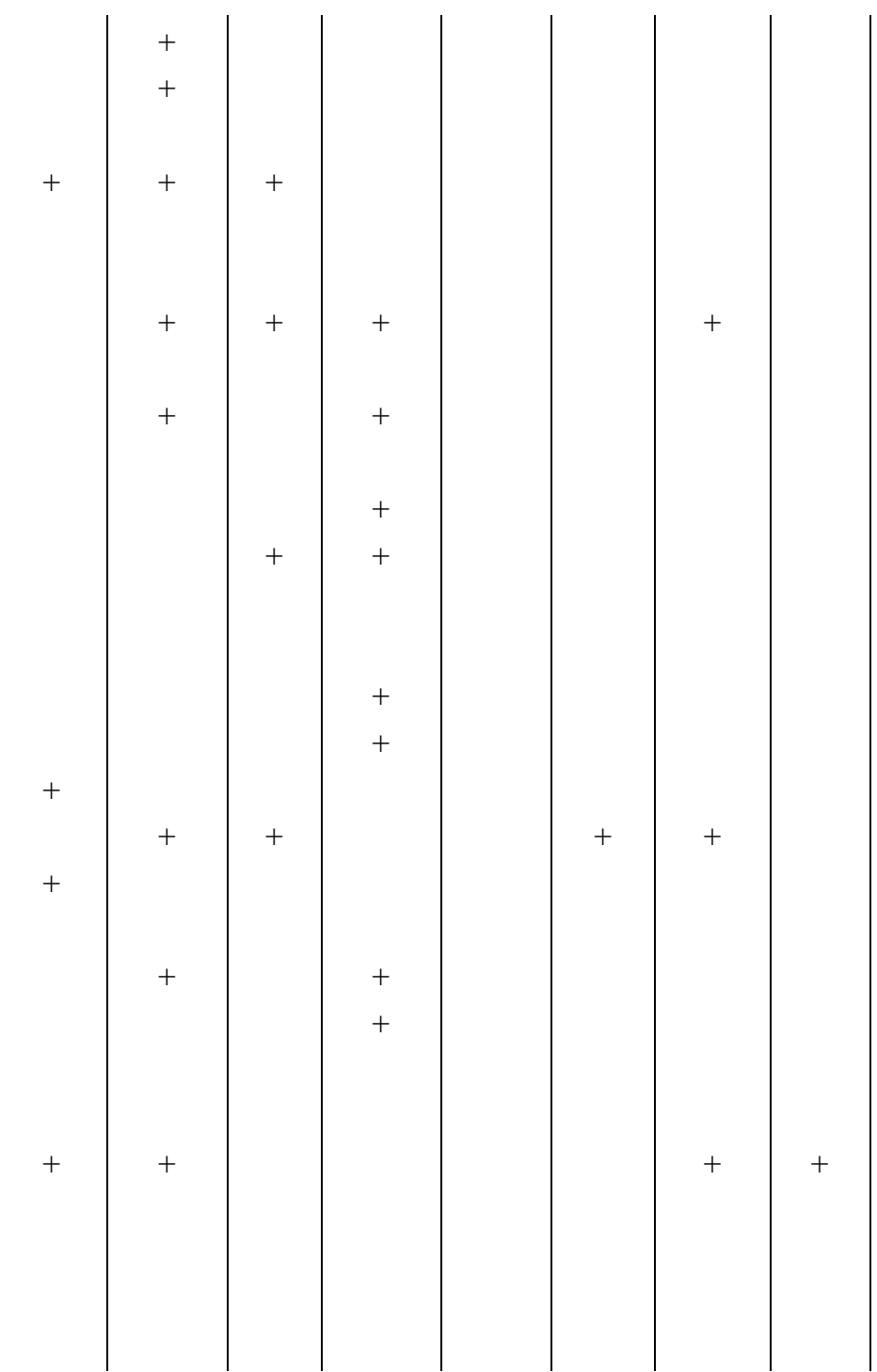

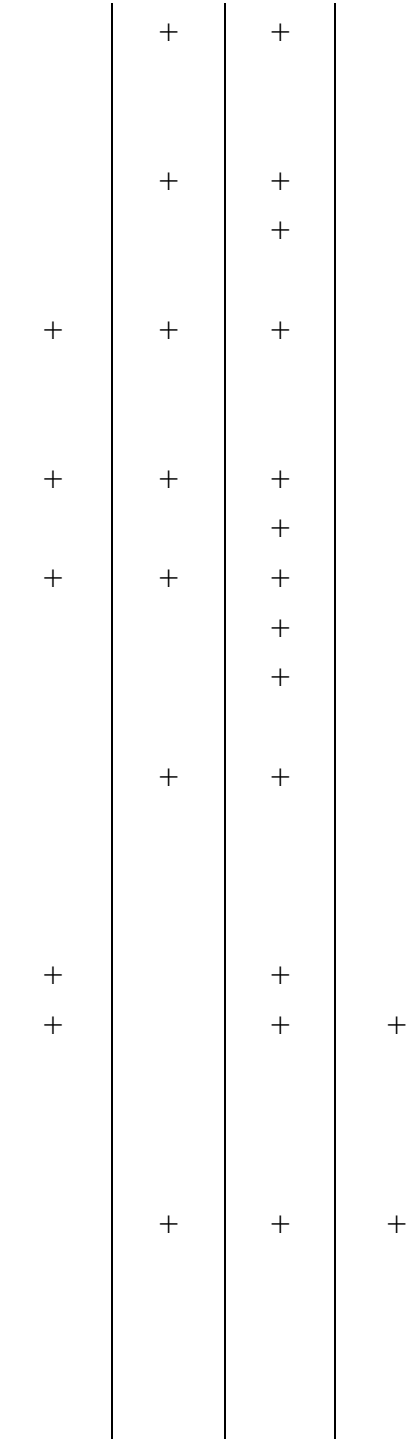

APPLIED ECOLOGY AND ENVIRONMENTAL RESEARCH 17(5):11341-11357.

http://www.aloki.hu • ISSN 15891623 (Print) • ISSN 17850037 (Online)

DOI: http://dx doi org/10_15666/aeer/1705_1134111357

(c) 2019, ALÖKI Kft., Budapest, Hungary 
Siniperca knerii

* Siniperca obscura

*Siniperca roulei

Siniperca scherzeri

Odontobutidae

*Micropercops swinhonis

\section{Gobiidae}

*Rhinogobius cliffordpopei

*Rhinogobius davidi

Rhinogobius giurinus

Osphronemidae

*Macropodus chinensis

Macropodus opercularis

\section{Channidae}

Channa asiatica

Channa maculata


APPLIED ECOLOGY AND ENVIRONMENTAL RESEARCH 17(5):11341-11357.

http://www.aloki.hu • ISSN 15891623 (Print) • ISSN 17850037 (Online)

DOI: http://dx doi org/10_15666/aeer/1705_1134111357

๑) 2019, ALÖKI Kft., Budapest, Hungary 